\title{
GAMBARAN DUKUNGAN SOSIAL, STRES, DAN ATTACHMENT PADA IBU DENGAN ANAK AUTISME DALAM MENGHADAPI PANDEMIK
}

\author{
${ }^{1}$ Magister Psikologi, Universitas Tarumanagara \\ Email: nevy.717182004@stu.untar.ac.id \\ ${ }^{2}$ Fakultas Psikologi, Universitas Tarumanagara \\ Emaill: samsunuwijatim@fpsi.untar.ac.id \\ ${ }^{3}$ Fakultas Psikologi, Universitas Tarumanagara \\ Email:naomis@fpsi.untar.ac.id
}

Nevy Prinanda Putri ${ }^{1}$, Samsunuwiyati Mar'at ${ }^{2}$, Naomi Soetikno $^{3}$

\begin{abstract}
Pandemics change a lot of activities, as well as patterns of activity of children with autism and interaction. Mothers as caregivers have to put in more effort to care for children during the pandemic so that stress levels also increase. This study aimed to see a picture of social support, stress and attachment to mothers with children with autism in a pandemic meeting. Participants in this study were 4 mothers who have children with autism. Sampling was done by convenience sampling. The method used is a qualitative method with a phenomenological design. The results shows that during the pandemic, the stress experienced by mothers with autism children who were received at a secondary assessment, understood their resources for coping and elicited emotional reactions such as anxiety that would develop rapidly. The attachment style of mothers with autism children is secure attachment based on the results of interviews, such as conducting joint interactions (meeting, playing, doing assignments, being responsive to needs and doing activities together) making necessary contact and adaptation to the pandemic. The description of social support during the pandemic of mothers with autistic children is a significant other, such as psychologists, baby sitters, and therapists. The main social support are direct assistance and information about the daily routine schedule that will be given to children with autism so that mothers with autistic children remain can carry out activities in a pandemic situation optimally.
\end{abstract}

Keywords: pandemic, social support, stress, attachment, mother, autism spectrum disorders

\begin{abstract}
ABSTRAK
Pandemik membuat banyak aktivitas berubah, begitu pula pola aktivitas anak dengan autisme dan ibunya. Ibu sebagai pengasuh utama harus mengeluarkan lebih banyak usaha untuk mengasuh anak pada masa pandemik sehingga tingkat stres juga meningkat. Penelitian ini bertujuan untuk melihat gambaran dukungan sosial, stres dan attachment pada ibu dengan anak autisme dalam menghadapi pandemik. Partisipan pada penelitian ini sebanyak 4 ibu yang memiliki anak dengan autisme. Pengambilan sampel dilakukan dengan convenience sampling. Metode yang digunakan adalah metode kualitatif dengan desain fenomenologi. Hasil penelitian menunjukkan bahwa gambaran stres selama pandemik yang dialami para ibu dengan anak autisme mengacu pada penilaian secondary appraisal, mengetahui sumber daya mereka untuk melakukan coping dan memunculkan reaksi emosional seperti cemas akan perkembangan anaknya. Gambaran attachment selama pandemik para ibu dengan anak autisme adalah secure attachment berdasarkan hasil wawancara, seperti melakukan interaksi bersama (kehadiran, bermain, mengerjakan tugas, responsif terhadap kebutuhan dan melakukan kegiatan bersama-sama) sehingga cenderung dapat menghadapi dan adaptasi terhadap situasi pandemik. Gambaran dukungan sosial selama pandemik para ibu dengan anak autisme adalah significant other yaitu tenaga profesional seperti psikolog, babysitter, terapis dan pihak sekolah berupa bantuan langsung maupun informasi mengenai jadwal rutinitas sehari-hari yang akan diberikan kepada anak dengan autisme sehingga ibu dengan anak autisme tetap dapat melakukan kegiatan dalam situasi pandemik secara optimal.
\end{abstract}

Kata Kunci: pandemik, dukungan sosial, stres, attachment, gangguan spektrum autism 


\section{PENDAHULUAN}

\section{Latar Belakang}

Coronavirus (COVID-19) telah menjadi pandemik sehingga pemerintah mengeluarkan keputusan yang menyatakan pembatasan untuk mencegah penyebarannya secara meluas (Nelson, 2020). Pada saat ini, belum ada vaksin atau obat yang mampu menyembuhkan penyakit ini (Chen et al., 2020), namun berita dari negara-negara menunjukkan bahwa jumlah kasus dan angka kematian meningkat dari hari ke hari. Sebagai hasil dari penyebaran wabah dan meningkatnya angka kematian, pada tanggal 30 Januari 2020, Organisasi Kesehatan Dunia (WHO) mendeklarasikan darurat kesehatan masyarakat global (WHO, 2020). Dalam berjuang melawan wabah, tindakan cepat dan protektif diambil oleh pemerintah Cina pertama kali dan kemudian diikuti oleh pemerintah negara lain di seluruh dunia.

Sejumlah langkah diambil oleh pemerintah, seperti (a) mengkarantina kota; (b) mengumumkan jam malam; (c) menutup area publik; (d) peringatan larangan bepergian; (e) izin publik untuk orang-orang dengan kondisi kronis atau usia lanjut; dan (f) penutupan sekolah. Langkah-langkah yang diambil untuk membatasi paparan publik terhadap virus mengharuskan seluruh lapisan masyarakat di seluruh dunia untuk tinggal di rumah, termasuk individu dengan kebutuhan khusus seperti Gangguan Spektrum Autisme (GSA). Dalam situasi ini penanganan anak-anak dengan kebutuhan khusus seperti anak dengan autisme dapat menjadi tantangan bagi keluarga dan pengasuh. Pada umumnya anak-anak dengan autisme memiliki intervensi (sekolah, terapi sensori integrasi, terapi perilaku, dan terapi wicara) selama beberapa jam seminggu di rumah dengan terapis khusus di rumah sakit atau lembaga khusus. Namun saat ini, karena adanya tindakan pencegahan wabah, keluarga dan anak-anak dengan autisme secara fisik tidak didukung oleh terapis dan tidak dapat menghadiri intervensi tersebut. Langkah-langkah tersebut diambil untuk kesehatan masyarakat, sehingga perlu ditangani dengan hati-hati untuk menghindari peningkatan stres orang tua dan memperburuk masalah perilaku anak-anak dengan autisme (Narzisi, 2020).

Banyak orangtua yang tidak dapat menutupi rasa stres, cemas, takut, putus asa, tidak mampu, dan panik dalam situasi pandemik. Terlebih lagi orangtua yang bekerja dari rumah (work from home) selama pandemik juga harus membagi waktu untuk mengajari anak dengan autisme belajar dari rumah (Study From Home) karena anak dengan autisme harus tetap memiliki rutinitas sehingga tantangan yang dihadapi semakin meningkat. Secara luas dilaporkan bahwa anak-anak dengan autisme memiliki defisit fungsi eksekutif dan anak-anak dengan autisme dapat menunjukkan masalah dalam kegiatan kehidupan sehari-hari mereka, terutama ketika rutinitas mereka tidak sesuai jadwal (Narzisi, 2020). Maka dari itu orangtua harus membuat struktur kegiatan kehidupan sehari-hari agar anak dengan autisme dapat menerapkan jadwal hariannya.

Altable (2020) menyatakan karantina anak dengan autisme di rumah juga memengaruhi emosinya karena keterbatasan aktivitas sehingga hal ini membuat anak dengan autisme merasa cemas dan memunculkan perilaku negatif seperti marah, menjerit-jerit, dan agresivitas. Sehingga merawat anak dengan autisme di saat pandemik seperti ini tidak mudah. Orang tua yang memiliki anak dengan autisme diketahui membutuhkan tenaga, usaha, waktu dan juga materi yang lebih besar untuk membesarkan anak dengan autisme.

Autisme atau dalam istilah klinis disebut Gangguan Spektrum Autisme (GSA) merupakan suatu gangguan perkembangan yang ditandai dengan dua gejala utama yaitu hambatan interaksi dan komunikasi sosial serta perilaku berulang dan terbatas (APA, 2013). Istilah GSA berdasarkan DSM-V (Diagnostic and Statistical Manual of Mental Disorder V), menjadi diagnosis tunggal yang menggantikan istilah gangguan perkembangan pervasif yang ditetapkan dalam DSM-IV, 
yang semula meliputi lima sub diagnosis yaitu gangguan autisme, sindrom asperger, gangguan perkembangan pervasif yang tidak spesifik, sindrom Rett dan gangguan disintegratif masa anak (Autism Research Institute, 2013).

Peran orangtua yang signifikan lebih intens dalam mengurus anak dan rumah adalah ibu. Sehingga stres yang dialami orangtua lebih besar dirasakan oleh ibu, karena ibu adalah orang yang paling sering kontak langsung dengan anak dibandingkan seorang ayah (Kuhlthau et al., 2014). Ibu rumah tangga menjadi salah satu posisi yang memiliki potensi mengalami stres dalam masa pandemik COVID 19. Hal tersebut terjadi karena munculnya sejumlah rutinitas baru di dalam rumah, salah satunya mengurus kegiatan sekolah anak yang diberikan secara online. Ibu rumah tangga yang memiliki anak dengan autisme selain harus mendampingi anak dalam tugas, juga harus membagi waktu dalam mengurus rumah tangga (masak, menyapu, mengepel, mencuci pakaian, menjemur pakaian, dan menyetrika pakaian) semua berubah jadwal kesehariannya. Terlebih jika dalam kondisi tertentu, banyak dari mereka yang mempunyai peran ganda, yaitu tidak hanya sebagai Istri bagi suaminya dan Ibu bagi anak-anaknya tetapi juga adalah seorang pekerja (working mother) yang ikut dalam mencari nafkah untuk membantu keluarganya. Kondisi pandemi COVID-19 juga mengharuskan setiap pekerja untuk aktif bekerjanya di rumah (work from home).

Stres adalah hubungan antara individu dengan lingkungannya yang dinilai oleh individu tersebut sebagai melebihi kemampuannya atau sumber dayanya dan mengancam kesejahteraannya (Lazarus \& Folkman, 1984). Terdapat lima faktor yang dapat menjadi stressor, yaitu frustrasi, konflik, tekanan, perubahan, dan self-imposed (Lazarus \& Folkman, 1984). Dua faktor yang menyebabkan situasi stres, yaitu yang berkaitan dengan individu dan yang berkaitan dengan situasi. Faktor personal berkaitan dengan intelektual, motivasi, dan karakteristik kepribadian. Karakteristik dari situasi yang menyebabkan stres antara lain adalah adanya perubahan dalam kehidupan (pindah komunitas, menjadi orangtua, pensiun, atau terkena penyakit kronis), waktu yang sulit (memiliki anak remaja di usia tua), ambiguitas (status kesehatan yang tidak jelas, opsi pengobatan), situasi yang menyebabkan hilangnya keinginan (kehilangan anggota keluarga atau pasangan), dan situasi yang sulit untuk dikontrol (kesulitan menghentikan pikiran yang traumatis, kesulitan untuk menjaga perilaku sehari-hari) (Lazarus \& Folkman, 1984).

Untuk mengatasi stres, para ibu membutuhkan strategi coping sebagai salah satu cara untuk menanggulangi stres. Salah satu coping yang dapat membantu ibu dapat merawat dan memberikan daily activity pada anak dengan autisme yaitu adanya dukungan sosial. Dukungan sosial cenderung dapat menurunkan stress pada seseorang dan menimbulkan pengaruh positif (Das et al., 2017). Bentuk dukungan sosial terhadap ibu yang mempunyai anak dengan GSA dapat berupa materi (dukungan instrumental), psikologis (dukungan emosional), dan informasi (dukungan informasional) (Ismail, 2008). Zimet (1988) menjelaskan bahwa dukungan sosial adalah dukungan yang bersifat subjektif yang sumber dukungannya dapat berasal dari keluarga, teman dan significant others.

Seperti hal nya pandemik saat ini ibu dan anak semakin intens sehingga diperlukan attachment yang aman agar anak dengan autisme dapat melakukan kegiatan dengan optimal saat di rumah dan selain itu dituntut menjadi pendamping, guru dan terapis bagi anak dengan autisme di rumah. Dukungan yang tersedia untuk membantu mengarahkan orangtua untuk melakukannya. Pertimbangan representasi attachment orangtua dapat bermanfaat dalam membantu orangtua mengetahui kebutuhan attachment anak-anak mereka dan mengelola stres dalam mengasuh anak dengan GSA (Seskin et al., 2010) terutama di saat pandemik. Anak dengan autisme diklasifikasikan aman jika mereka telah meningkatkan kapasitas untuk tampilan afektif dan 
pemahaman sosial, dan ibu dengan anak autisme menunjukkan sensitivitas yang lebih besar (Shapiro et al., 1987; Capps et al. dalam Rozga et al., 2018).

Ibu dengan dukungan sosial dari orang terdekat maupun tenaga profesional cenderung mendapatkan pengetahuan dan cenderung mengaplikasikan interaksi terhadap anak sehingga terjalin attachment yang positif (Sari et al., 2018). Dari fenomena tersebut belum ada vaksin atau obat yang mampu menyembuhkan penyakit ini (Chen et al., 2020). Orangtua yang bekerja dari rumah (work from home) selama pandemik juga harus membagi waktu untuk mengajari anak dengan autisme belajar dari rumah (Study From Home) karena anak dengan autisme harus tetap memiliki rutinitas sehingga tantangan yang dihadapi semakin meningkat. Secara luas dilaporkan bahwa anak-anak dengan autisme memiliki defisit fungsi eksekutif dan anak-anak dengan autisme dapat menunjukkan masalah dalam kegiatan kehidupan sehari-hari mereka, terutama ketika rutinitas mereka tidak sesuai jadwal (Narzisi, 2020). Oleh karena itu, peneliti tertarik untuk meneliti bagaimana ibu merasakan stres saat pandemi dan dukungan sosial dari pihak mana yang dibutuhkan pada saat pandemik serta attachment ibu dengan anak autisme dalam menghadapi pandemik karena pandemik belum dapat diprediksi pemulihannya. Berdasarkan uraian diatas, peneliti tertarik untuk melihat gambaran stres, attachment dan dukungan sosial pada ibu dengan anak autisme dalam menghadapi pandemik.

\section{Rumusan Masalah}

Bagaimana gambaran stres, attachment dan dukungan sosial pada ibu dengan anak autisme dalam menghadapi pandemi?

\section{METODE PENELITIAN}

Penelitian ini menggunakan desain penelitian fenomenologi dengan jenis pendekatan penelitian kualitatif. Penelitian ini memiliki fokus untuk melihat gambaran dukungan sosial, stres dan attachment ibu dengan anak autisme dalam menghadapi pandemik. Bagaimana gambaran dukungan sosial, stres, dan attachment ibu dengan anak autisme dalam menghadapi pandemik. Kemudian menghubungi ibu yang memiliki anak dengan autisme untuk melakukan wawancara, lalu hasil wawancara dilakukan verbatim, coding dan menganalisa hasil wawancara tersebut.

\section{Partisipan}

Partisipan dalam penelitian ini terdapat 4 partisipan. Dengan kriteria partisipan (a) ibu yang memiliki anak dengan diagnosa autisme, kriteria ini memilih ibu yang setidaknya memiliki 1 anak dengan autisme karena ibu dengan autisme sesuai dengan fenomena yang telah dijabarkan pada latar belakang; (b) usia anak dengan autisme minimal 5 tahun - maksimal 15 tahun, dikarenakan pada usia tersebut anak belum memiliki kemandirian yang cukup untuk mampu mengurus dirinya sendiri; (c) mengikuti terapi, supaya mengetahui kekurangan dan kelebihan pada anak dengan autisme; (d) pekerjaan ibu tidak dibatasi, karena ingin mengetahui hasil gambaran secara keseluruhan.

\section{Instrumen Penelitian}

Instrumen yang digunakan dalam proses yaitu laptop dan handphone. Sedangkan untuk mengumpulkan data dalam penelitian ini terdiri dari: (1) Informed consent melalui rekaman media telepon dengan cara partisipan membacakan kembali pernyataan yang dibacakan oleh pemeriksa sebagai persetujuan sebagai partisipan penelitian ini; dan (2) lembar pedoman wawancara terhadap ibu sebagai partisipan. 


\section{Prosedur}

Melakukan pilot study sebagai langkah awal untuk meneliti penelitian ini secara komprehensif. Pilot study dilakukan dengan cara melakukan survey melalui wawancara secara online dengan media perpesanan whatsapp mengenai gambaran dukungan sosial, stres dan attachment ibu dengan anak autisme dalam menghadapi pandemik. Data pilot study ini digunakan untuk mengetahui fenomena di lapangan dan mempertajam hipotesis dan pertanyaan penelitian. Data pilot study memberikan informasi yang diperlukan tidak hanya untuk menghitung ukuran sampel, tetapi juga untuk penilaian semua aspek lain dari studi utama. Selanjutnya proses observasi dilakukan dengan mendengarkan intonasi suara pada partisipan saat wawancara dan metode wawancara mendalam atau in-depth interview dipergunakan untuk memperoleh data dengan metode wawancara pada partisipan yang akan diwawancara mengenai gambaran dukungan sosial, stres, dan attachment ibu dengan anak autisme dalam menghadapi pandemik. Partisipan yang bersedia dihubungi melalui media telepon akan direkam selama proses wawancara.

\section{HASIL DAN PEMBAHASAN}

Hasil penelitian menunjukkan bahwa gambaran stres selama pandemik yang dialami para ibu dengan anak autisme mengacu pada penilaian secondary appraisal, mengetahui jenis coping yang bisa dilakukan dalam menghadapi situasi-situasi yang dan memunculkan reaksi emosional seperti cemas akan perkembangan anaknya. Gambaran attachment selama pandemik para ibu dengan anak autisme adalah secure attachment melalui wawancara, seperti melakukan interaksi bersama (kehadiran, bermain, mengerjakan tugas, responsif terhadap kebutuhan dan melakukan kegiatan bersama-sama) sehingga cenderung dapat menghadapi dan adaptasi terhadap situasi pandemik. Hal ini didukung pada penelitian Seskin et al (2010) yang menyatakan representasi attachment orangtua dapat bermanfaat dalam membantu orangtua mengetahui kebutuhan attachment anakanak mereka dan mengelola stres dalam mengasuh anak dengan GSA. Gambaran dukungan sosial selama pandemik para ibu dengan anak autisme adalah significant other yaitu tenaga profesional seperti psikolog, babysitter, terapis dan pihak sekolah berupa bantuan langsung maupun informasi mengenai jadwal rutinitas sehari-hari yang akan diberikan kepada anak dengan autisme sehingga ibu dengan anak autisme tetap dapat melakukan kegiatan dalam situasi pandemik secara optimal. Hal ini juga didukung penelitian Sari et al. (2018) yang menjelaskan bahwa ibu dengan dukungan sosial dari orang terdekat maupun tenaga profesional cenderung mendapatkan pengetahuan dan cenderung mengaplikasikan interaksi terhadap anak sehingga terjalin attachment yang positif.

\section{Tabel 1}

\begin{tabular}{|c|c|c|c|c|}
\hline Stres & Subyek 1 & Subyek 2 & Subyek 3 & Subvek 4 \\
\hline \multirow[t]{2}{*}{ Stressor } & Konflik & Konflik & Tekanan & Ancaman \\
\hline & $\begin{array}{l}\text { (kebutuhan terapi } \\
\text { anak namun } \\
\text { pandemik dan } \\
\text { membagi waktu } \\
\text { mengurus rumah) }\end{array}$ & $\begin{array}{l}\text { (kebutuhan terapi } \\
\text { anak namun } \\
\text { pandemik dan } \\
\text { harus membagi } \\
\text { waktu WFH dan } \\
\text { SFH) }\end{array}$ & $\begin{array}{c}\text { (tidak percaya diri } \\
\text { dapat mendampingi } \\
\text { dan mengajari anak } \\
\text { saat belajar) }\end{array}$ & $\begin{array}{l}\text { (sikap suami, } \\
\text { perlakuan tidak } \\
\text { menyenangkan } \\
\text { dari suami } \\
\text { terhadap anak) }\end{array}$ \\
\hline $\begin{array}{l}\text { Penilaian } \\
\text { terhadap Stres }\end{array}$ & $\begin{array}{l}\text { Primary appraisal } \\
\text { (challenge, Tuhan } \\
\text { memberikan } \\
\text { cobaan tanpa } \\
\text { solusi } \\
\text { "pandemik") }\end{array}$ & $\begin{array}{c}\text { Primary appraisal } \\
\text { (challenge, masa } \\
\text { pandemik anak } \\
\text { tidak bisa terapi } \\
\text { sensori integrasi, } \\
\text { namun ia berusaha }\end{array}$ & $\begin{array}{c}\text { Primary appraisal } \\
\text { (Threat, kepikiran } \\
\text { dan khawatir akan } \\
\text { kemunduran } \\
\text { anaknya di saat } \\
\text { pandemik dan }\end{array}$ & $\begin{array}{c}\text { Primary appraisal } \\
\text { (challenge, yakin } \\
\text { bahwa apapun } \\
\text { yang terjadi Tuhan } \\
\text { sudah } \\
\text { mengaturnya) }\end{array}$ \\
\hline
\end{tabular}




\begin{tabular}{|c|c|c|c|c|}
\hline & & $\begin{array}{l}\text { meminta terapis } \\
\text { lain yang } \\
\text { mengerjakannya } \\
\text { di rumah) }\end{array}$ & $\begin{array}{c}\text { merasa tidak } \\
\text { mampu untuk } \\
\text { mengajari anaknya } \\
\text { dalam belajar) }\end{array}$ & \\
\hline & $\begin{array}{c}\text { Secondary } \\
\text { appraisal } \\
\text { (sumber daya yang } \\
\text { dimiliki adalah } \\
\text { Tuhan) }\end{array}$ & $\begin{array}{c}\text { Secondary } \\
\text { appraisal } \\
\text { (sumber daya yang } \\
\text { dimiliki adalah } \\
\text { terapis yang tetap } \\
\text { datang ke rumah) }\end{array}$ & $\begin{array}{c}\text { Secondary } \\
\text { appraisal } \\
\text { (sumber daya yang } \\
\text { dimiliki adalah } \\
\text { nanny yang } \\
\text { membantu secara } \\
\text { langsung mengasuh } \\
\text { anaknya) }\end{array}$ & $\begin{array}{c}\text { Secondary } \\
\text { appraisal } \\
\text { (sumber daya yang } \\
\text { dimiliki adalah } \\
\text { Tuhan, sehingga } \\
\text { merasa bersyukur } \\
\text { dalam keadaan } \\
\text { apapun) }\end{array}$ \\
\hline Reaksi Stres & $\begin{array}{l}\text { Reaksi emosional } \\
\text { (merasa cemas, } \\
\text { namun tetap } \\
\text { bersyukur karena } \\
\text { anak dan keluarga } \\
\text { masih diberikan } \\
\text { kesehatan) }\end{array}$ & $\begin{array}{l}\text { Reaksi emosional } \\
\text { (merasa khawatir, } \\
\text { namun berusaha } \\
\text { memenuhi terapi } \\
\text { anak dengan } \\
\text { autisme selama } \\
\text { pandemik di } \\
\text { rumah }\end{array}$ & $\begin{array}{c}\text { Reaksi kognitif } \\
\text { (tidak mampu } \\
\text { berkonsentrasi) } \\
\\
\text { Reaksi emosinal } \\
\text { (khawatir anak } \\
\text { dengan autisme } \\
\text { tidak dapat } \\
\text { berinteraksi secara } \\
\text { sosial selama } \\
\text { pandemik) }\end{array}$ & $\begin{array}{c}\text { Reaksi emosional } \\
\text { (merasa kesal dan } \\
\text { khawatir, namun } \\
\text { percaya bahwa } \\
\text { Tuhan } \\
\text { memberikannya } \\
\text { kekuatan dalam } \\
\text { setiap doa yang } \\
\text { dihaturkan) }\end{array}$ \\
\hline \multirow[t]{2}{*}{ Jenis Coping } & & $\begin{array}{l}\text { Problem focused } \\
\text { coping }\end{array}$ & $\begin{array}{l}\text { Problem focused } \\
\text { coping }\end{array}$ & $\begin{array}{c}\text { Problem focused } \\
\text { coping }\end{array}$ \\
\hline & $\begin{array}{l}\text { Emotional focused } \\
\text { coping } \\
\text { (self control, } \\
\text { menggunakan } \\
\text { aplikasi "tik tok") }\end{array}$ & $\begin{array}{l}\text { (seeking social } \\
\text { support, masih } \\
\text { adanya bantuan } \\
\text { terapis yang } \\
\text { datang ke rumah } \\
\text { saat pandemik) }\end{array}$ & $\begin{array}{c}\text { (seeking social } \\
\text { support, guru kelas } \\
\text { masih memberikan } \\
\text { tugas sehari-hari } \\
\text { sehingga masih ada } \\
\text { kegiatan dan } \\
\text { bantuan nanny } \\
\text { mendampingi } \\
\text { anaknya belajar } \\
\text { sangat membantu) }\end{array}$ & $\begin{array}{c}\text { (seeking social } \\
\text { support, suami } \\
\text { ikut serta menjaga } \\
\text { anak-anak selama } \\
\text { pandemik) }\end{array}$ \\
\hline
\end{tabular}

\section{Tabel 2}

Attachment

\begin{tabular}{lcccc}
\hline Tipe Attachment & Subyek 1 & Subyek 2 & Subyek 3 & Subyek 4 \\
\hline Secure & Merasa eye & Selama pandemik & Merasa selama & Merasa selama \\
attachment & contact anak & lebih banyak waktu & pandemik intens & pandemik harus \\
& semakin membaik & bersama dengan & bersama anak, & tetap mengulang \\
& terutama saat & anaknya di rumah & mengajak anak & pembelajaran agar \\
& bermain dan & sehingga & berbicara & anak tidak lupa \\
& kehadiran ibu saat & mengetahui & sehingga melihat & (kehadiran ibu dan \\
& melakukan & kekurangan dan & perubahan anak & responsif terhadap \\
& kegiatan serta & kelebihan pada & semakin banyak & kebutuhan anak) \\
& responsive & anak, kehadiran ibu & bicara selama di & dan merasa selama \\
& terhadap & saat anak terapi di & rumah. & pandemik \\
\hline
\end{tabular}




$\begin{array}{cc}\text { kebutuhan anak } & \text { rumah serta ibu } \\ \text { selama pandemik. } & \text { responsif terhadap } \\ & \text { kebutuhan anak } \\ & \text { untuk terapi selama } \\ & \text { pandemik. }\end{array}$

keterampilan anak

bertambah.

Tabel 3

Dukungan Sosial

\begin{tabular}{|c|c|c|c|c|}
\hline $\begin{array}{c}\text { Dukungan } \\
\text { Sosial }\end{array}$ & Subyek 1 & Subyek 2 & Subyek 3 & Subyek 4 \\
\hline \multirow[t]{2}{*}{ Jenis } & Teman & $\begin{array}{l}\text { Significant other } \\
\text { (Nanny, terapis dan } \\
\text { group) }\end{array}$ & $\begin{array}{c}\text { Significant other } \\
\text { (Nanny, } \\
\text { pembimbing) }\end{array}$ & $\begin{array}{c}\text { Keluarga } \\
\text { (Suami) }\end{array}$ \\
\hline & $\begin{array}{l}\text { (menjadi tempat } \\
\text { bercerita dan } \\
\text { mendapatkan } \\
\text { informasi) }\end{array}$ & $\begin{array}{l}\text { (bantuan secara } \\
\text { langsung mengurus } \\
\text { rumah dan anak serta } \\
\text { informasi dari group) }\end{array}$ & $\begin{array}{c}\text { (membantu dalam } \\
\text { pengasuhan anaknya } \\
\text { dan pembimbing } \\
\text { membantu dalam } \\
\text { pemberian tugas } \\
\text { sehari-hari dan } \\
\text { informasi mengenai } \\
\text { kegiatan) }\end{array}$ & $\begin{array}{c}\text { (membantu } \\
\text { menjaga anak- } \\
\text { anak dan } \\
\text { pekerjaan rumah } \\
\text { tangga) }\end{array}$ \\
\hline
\end{tabular}

\section{KESIMPULAN DAN SARAN}

Berdasarkan data di atas gambaran dukungan sosial para ibu yang mempunyai anak dengan autisme selama pandemik adalah significant other yaitu tenaga profesional seperti terapis, babysitter, dan pihak sekolah berupa bantuan langsung maupun informasi mengenai jadwal rutinitas sehari-hari yang akan diberiikan kepada anak dengan autisme sehingga ibu dengan anak autisme tetap dapat melakukan kegiatan dalam situasi pandemik secara optimal.

Gambaran stres para ibu yang mempunyai anak dengan autisme selama pandemik mengacu pada penilaian primary appraisal and secondary appraisal yaitu kondisi pandemik sebagai primary appraisal dengan memaknai sebagai challenge sehingga dapat mengatasi atau mendapatkan keuntungan dari suatu peristiwa, para ibu beradaptasi dengan keadaan pandemik, dengan berbagai cara agar anak dengan autisme tetap mendapatkan aktivitas, memenuhi kebutuhan sehari-hari , memberikan pemahaman tentang COVID 19, dan mengajarkan kebersihan agar anak dengan autisme tetap sehat selama di rumah. Mengetahui sumber daya mereka (secondary appraisal) dengan cara tetap bersyukur serta berdoa kepada Tuhan Yang Maha Esa. Reaksi stres yang dirasakan masing-masing ibu yaitu beberapa ibu mengalami reaksi emosional dan beberapa ibu mengalami reaksi tingkah laku terhadap stres. Reaksi emosional yang dinyatakan berupa rasa khawatir, cemas dan marah karena apa yang diharapkan dalam keadaan pandemik tidak dapat diprediksi. Selain itu reaksi tingkah laku yang dinyatakan berupa doa sehingga menjadikan hati tenang dan kuat. Penggunaan aplikasi "tik tok" dapat mengembalikan mood serta mengurangi dan menghilangkan hal-hal negatif. Kemudian stres yang dirasakan para ibu selama pandemik dapat diatasi dengan coping stress yang berasal dari seeking social support baik berupa bantuan secara langsung maupun informasi agar kegiatan sehari-hari pada anak autisme tetap berjalan dan optimal. 
Gambaran attachment para ibu yang mempunyai anak dengan autisme selama pandemik adalah secure attachment, hal ini berkaitan dengan selama pandemik para ibu dan anak bertemu secara intens sehingga adanya dukungan sosial yang berasal dari significant other yaitu terapis dan babysitter) membuat para ibu mendapatkan pengetahuan dalam melakukan bonding kepada anak dengan autisme seperti melakukan interaksi bersama (kehadiran ibu, bermain dengan ibu, ibu mendampingi dan mengajarkan anak mengerjakan tugas, ibu responsif terhadap kebutuhan anak dan melakukan kegiatan sehari-hari bersama) sehingga cenderung para ibu mengetahui kekurangan maupun kelebihan serta melihat perubahan yang lebih ke arah positif terhadap anak selama berada di rumah. Serta adanya bantuan secara langsung dari babysitter meringankan para ibu untuk bergantian mengasuh di saat pandemik.

Pada peneliti selanjutnya, dapat melakukan wawancara dan observasi secara langsung sehingga mendapatkan informasi secara detail. Selain itu untuk karakteristik ibu pada penelitian selanjutnya lebih seragam. Serta dalam penelitian selanjutnya dapat menggunakan metode Mixed Method Research sehingga mendapatkan jumlah partisipan lebih banyak sehingga menggambarkan dukungan sosial, stres dan attachment pada ibu dengan anak autisme dalam menghadapi pandemik.

\section{REFERENSI}

Altable, M. (2020). Child and Adult Autism Spectrum Disorder in COVID-19 Pandemic. Qeios. APA. (2013). Diagnostic And Statistical Manual of Mental Disorder Edition "DSM-5". Washinton DC: American Psychiatric Publishing. Washinton DC.

Autism Research Institute. (2013). DSM-V: What Changes May Mean. Diunduh dari https://www.autism.com/news_dsmV tanggal 3 Oktober 2019.

Chen, N., Zhou, M., Dong, X., Qu, J., Gong, F., Han, Y., ... \& Zhang, L. (2020). Epidemiological and clinical characteristics of 99 cases of 2019 novel coronavirus pneumonia in Wuhan, China: a descriptive study. The lancet, 395(10223), 507-513.

Dardas, L. A., \& Ahmad, M. M. (2014). Quality of life among parents of children with autistic disorder: A sample from the Arab world, Research in Developmental Disabilities. Elsevier Ltd, 35(2), pp. 278-287. doi: 10.1016/j.ridd.2013.10.029.

Ismail, A. (2008). Hubungan antara dukungan sosial dengan penerimaan diri ibu dari anak Autis. (Skripsi, Fakultas Psikologi Universitas Katolik Soegijapranata).

Kuhlthau, K. et al. (2014). Quality of life for parents of children with autism spectrum disorders ${ }^{\text {ee }}$, Research in Autism Spectrum Disorders. Elsevier Ltd, 8(10), pp. 1339-1350. doi: 10.1016/j.rasd.2014.07.002.

Lazarus, R., \& Folkman, S. (1984). Stress, appraisal, and coping. Springer Publishing Company.

Narzisi, A. (2020). Handle the autism spectrum condition during Coronavirus (COVID-19) stay at home period: Ten tips for helping parents and caregivers of young children.

Nelson, C.W. COVID-19: Time for WHO to reconsider its stance towards Taiwan. Nature 2020, 579, 193.

Rozga, A., Hesse, E., Main, M., Duschinsky, R., Beckwith, L., \& Sigman, M. (2018). A shortterm longitudinal study of correlates and sequelae of attachment security in autism. Attachment \& human development, 20(2), 160-180.

Sari, S. L., Devianti, R., \& Safitri, N. (2018). Kelekatan orangtua untuk pembentukan karakter anak. Educational Guidance and Counseling Development Journal, 1, 17-31.

Seskin, L., Feliciano, E., Tippy, G., Yedloutschnig, R., Sossin, K. M., \& Yasik, A. (2010). Attachment and autism: Parental attachment representations and relational behaviors in the parent-child dyad. Journal of abnormal child psychology, 38(7), 949-960. 
World Health Organization (WHO). (2020). WHO Director-General's opening remarks at the media briefing on COVID-19. https://www.who.int/dg/speeches/detail/who-directorgeneral-s-opening-remarks-at-the-media-briefing-on-covid-19---11-march-2020.

Zimet, G. D., Dahlem, N. W., Zimet, S. G., \& Farley, G. K. (1988). The multidimensional scale of perceived social support. Journal of personality assessment, 52(1), 30-41. 